\title{
THE EFFECTS OF SOCIAL FACTORS ON THE ADOPTION OF RICE PRODUCTION TECHNOLOGIES IN ZONE C OF BENUE STATE, NIGERIA
}

\author{
Efek Faktor Sosial dalam Penerapan Teknologi Produksi Padi \\ di Zona C Negara Bagian Benue, Nigeria
}

\author{
Ejembi, S.A. ", Orkpe, F., Bello, G.O. \\ Department of Agricultural Extension and Communication, \\ University of Agriculture, Makurdi, Nigeria \\ *Kontak penulis: amesimmon72@gmail.com
}

\begin{abstract}
Abstrak
Penduduk Nigeria seperti pada bagian lain dunia terus melambung sehingga memerlukan peningkatan produktivitas pertanian dan ketahanan pangan. Untuk memenuhi kebutuhan pangan, perlu dilakukan peningkatan produksi melalui teknologi yang tepat. Di sebagian besar wilayah Nigeria, adopsi teknologi pertanian masih rendah. Penelitian ini bertujuan untuk menganalisa pengaruh karakteristik sosial petani terhadap keputusannya mengadopsi teknologi produksi padi. Penelitian dilakukan di Zona $\mathrm{C}$ dari Negara Bagian Benue yang dipilih secara purposif karena di daerah ini tersedia areal pertanian yang sesuai untuk pertanaman padi. Seratus responden dipilih melalui teknik simple random sampling. Statistik deskriptif (persentase dan frekuensi) dan statistik inferensial (Model Regresi Biner Logit) digunakan untuk analisis data. Hasil penelitian menunjukkan bahwa mayoritas reponden (55\%) adalah laki-laki, $48 \%$ memiliki pengalaman bertani antara 620 tahun, $49 \%$ memiliki kualifikasi pendidikan tersier, $62 \%$ bukan berasal dari kelompok tani, 51\% tidak memiliki kontak dengan penyuluh dan $56 \%$ responden memperkirakan pendapatan tahunan mereka rata-rata 120, 000.00. Pada umumnya responden memperoleh informasi pertanian utama melalui radio, 93\% mengungkapkan bahwa teknologi benih merupakan teknologi utama yang tersedia bagi petani. Hasil regresi logit menunjukkan bahwa pendidikan $(\mathrm{W}=9.600)$, dan luas lahan $(\mathrm{W}=2.051)$ secara signifikan mempengaruhi keputusan adopsi petani. Berdasarkan temuan ini, disimpulkan bahwa tingkat adopsi yang rendah karena tidak adanya teknologi baru selain benih yang lebih baik, dan juga tidak adanya penyuluhan. Oleh karena itu, direkomendasikan agar organisasi petani diperkuat agar mereka dapat mengatur layanan penyuluhan mereka sendiri.
\end{abstract}

Kata Kunci: adopsi teknologi; faktor sosial; teknologi baru; penyuluhan pertanian.

Citation: Ejembi, S.A., Orkpe, F., Bello, G.O. The Effects of Social Factors on The Adoption of Rice Production Technologies in Zone C of Benue, Nigeria, JSEP 14(1): 55 - 64.

\section{Introduction}

There is a premium on food security and sustainable agricultural production practices especially in the third world where the risk of food insecurity is highest. This is particularly necessary with the geometric increase in population growth rate. Nigeria currently has an estimated population of over 170 million people with majority living in the rural areas depending comprehensively on agriculture (Lawal, 2009). Agriculture is the main stay of rural Nigeria as the land and weather conditions are suitable for all crops including rice.

Rice (Oryza sativa) is the most important staple food for about half of the human race (Imolehim and Wada, 2000). Saka and Lawal (2009) classified rice as the most important food depended upon by over 50 percent of the World population for 
about 80 percent of their food need. Due to the growing importance of the crop, Food and Agricultural Organization (2001) estimated that annual rice production should be increased from 586 million metric tons in 2001 to meet the projected global demand of about 756 million metric tons by 2030 .

Research has shown that production and processing technologies have not been able to meet the increasing demand for rice (FAO, 2001). In the West African sub region, Nigeria has experienced is experiencing a growing demand for rice caused by rising per capita consumption and consequently the insufficient domestic production had to be complemented with enormous import both in quantity and value at various times (Saka and Lawal, 2009). This situation has an overbearing effect of the country's foreign reserve and so the need for improved technology to boost location production such that burden of importation can be ameliorate as improving of farmers' living standards.

Agricultural technologies refer to use of modern machineries and ideas to improve farmers' skills and efficiency. Successive governments in Nigeria evolved agricultural policies and programmes to guarantee innovative agriculture if those technologies were adopted. Adoption on the other hand is the decision of farmers to accept and practice an idea introduced to them through effective extension services. This decision is dependent on several factors which can be classified as social, economic, psychological and institutional factors. Decision making process is key to effective grass root development. However, many people are unable to make effective development decision because of the level of disenchantment occasioned by marginalization and social exclusion which apparently deprived these categories of people from accessing to democracy dividends. This study focuses on the social factors affecting adoption of innovation in Zone C of Benue State Nigeria.

Rice yield in Nigeria and particularly in Benue State has been on the decline due to problems such as outdated farming practices, parasitic weeds, insects and diseases (FAO, 2014).According to the Africa Rice Center, the limited growth of the aggregate productivity of rice in Africa is due to the large share of rain-fed rice and subsistence based rice farming systems (IRRI, 1996). Improvement in rice productivity potential will therefore play a critical role in feeding the African population that is expected to double during the next two decades. Therefore, there is a need to support farmers to increase rice productivity rather than acreage cultivated, if Africa is to meet the short-fall in rice production.

In an effort to boost rice production in West Africa (Ghana, Mali, Nigeria and Senegal), a two-year Emergency Rice Initiative Project (ERIP) was initiated in 2009. The emergency initiative aimed to boost rice production through enhancing farmer access to certified seed of improved rice varieties, mineral fertilizer and knowledge on best-bet rice production technologies in the target countries, thereby reducing rice imports and averting the need for costly food relief actions. This initiative is in addition to the agricultural extension project and Sasakawa Global 2000 (SG, 2000) (Saka and Lawal, 2009).

Unfortunately, the Nigerian agricultural sector is characterized by low level of technology adoption making these programmes of no impactful effects. Available evidence shows that adoption level is very low compared to the efforts put into the formulation of such polices and programmes as exemplified by farmers' low productivity. According to Food and Agriculture Organization (2010), this 
contributes to the low agricultural productivity in the country. This low capacity has been attributed to several factors; notable among them is the declining productivity due to low adoption of improved production practices (Ejembi, Omoregbee and Ejembi, 2006).

Many studies on rice technology adoption have been conducted in developing nations including Nigeria (Dontsop, 2011). However, because of variability in natural resources, culture, political system, traditions, beliefs and socio-economic factors, the factors affecting technology adoption differs across the locations. For instance, in a review of technology adoption studies in Africa FAO (2001) showed that factors that affect technology adoption vary among locations, hence the need to carry out an analysis of the effects of social factors affecting adoption of rice technologies in Zone C of Benue State, Nigeria.

In order to effectively carry out this analysis, the following research questions were formulated:

a. What are the socio-economic characteristics of rice farmers in the study area?

b. What are the sources of information on rice production technologies by the farmers?

c. What rice production technologies have been introduced to the farmers in the study area?

d. What are the effects of social characteristics on respondents' adoption decision

The broad objective of the study is to investigate the factors affecting the adoption of rice production technologies in Apa local government area, Benue state, Nigeria.

The specific objectives of the study are to:

a. describe the socio-economic characteristics of rice farmers in the study area;

b. identify the sources of information on rice production technologies by the farmers;

c. identify the rice production technologies that have been introduced to the farmers in the study area;

d. determine the effects of respondents' social characteristics on adoption decisions and Based on the specific objectives, the following hypothesis was tested:

$\mathrm{H}_{01}$ : farmers' social characteristics have no significant effects on the adoption of rice technologies in the study area.

\section{Method}

This study was carried out in Zone C of Benue State, Nigeria which was purposively selected due to the people's high involvement in rice production. Benue state is divided into three agricultural zones $\mathrm{A}, \mathrm{B}$, and $\mathrm{C}$ for administrative convenience. Due to the homogenous nature of the zone the involvement of the people in rice production, Apa Local Government Area was purposively selected for this study. The local government is located in the northwestern part of Makurdi, the capital of Benue State. It is bounded to the North by Agatu local government, to the West by Gwer West, to the South by Otukpo and to West by Omala local government area of Kogi State. It has population of about 250,000 people with a population 
density of about 200,300 persons per sq. $\mathrm{km}$ (NPC, 2006). The local government has 11 council wards namely, Ugbokpo, Edikwu I, Ikobi, Akpete, Oba, Iga, Oiji, Ojope, Igoro, Edikwu II and Auke.

The local government has agricultural potentials and products of commercial significance. This includes yams, maize, guinea-corn, rice, soybeans, millet, beniseed, beans, groundnuts, bambara nuts, citrus fruits, mangoes, cashew, pineapple, guava, palm products, pepper and cassava. These agricultural potentials are capable of conveniently supporting agro-allied industries like rice milling, palm kernel processing, garri processing flour milling, juice processing, bakery, oil mills, food processing, timber-lumbering and ceramic. The people of the local government, in addition to farming, engage in trading (NPC, 2006).

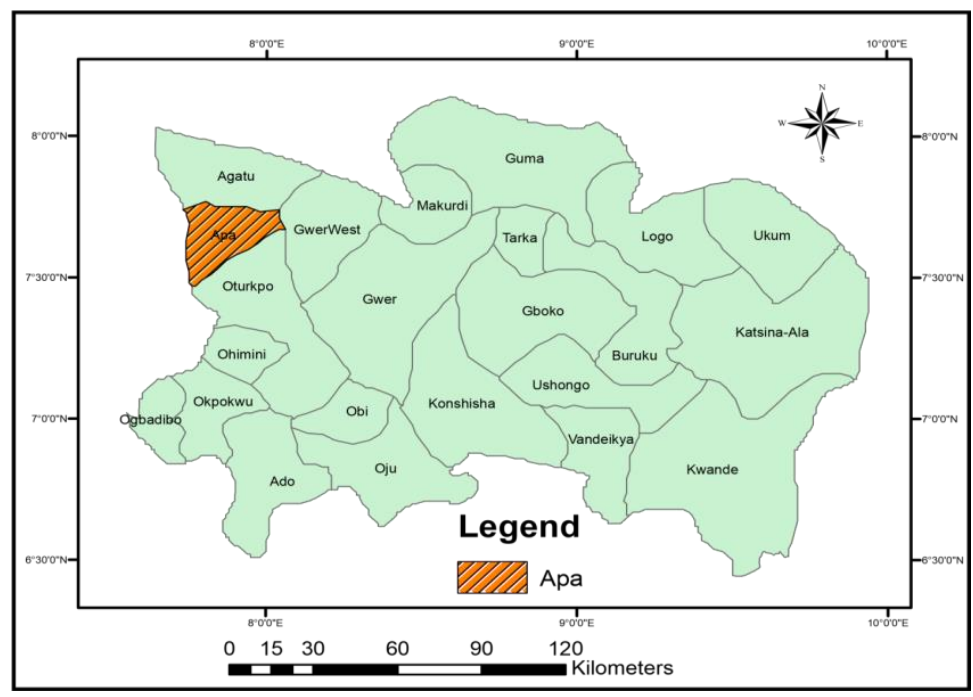

Figure 1. Map of Benue State Showing The Study Area (Apa) Source: Created from Nigeria shelf Archives (2017)

The population of the study consisted of all rice farmers in Apa Local Government Area, Benue State, however due to logistics purposive and multistage sampling technique was adopted to select 100 respondents from whom primary data was collected for this study.

The data for this study were analyzed using both descriptive and inferential statistics. Objectives 1, 2 and 3 was analyzed using descriptive statistics such as frequency, percentages and mean scores and objective 4 was analysed using binary logit regression analysis and the parameters used to test the stated hypothesis. The logit model is appropriate because the dependent variable, adoption of technologies is qualitative in nature and will hence measure at two levels as dummy variable $(1=$ adopted and $0=$ not adopted). The logit regression model is a binary choice technique, which allows for prediction of effects of independent variables on the dependent variable. The logit model is chosen as the best approach used for handling multinomial dependent variable (Manyong and Houndekon, 2000 ). In estimable form, the model is expressed as;

$$
Z=\operatorname{Ln}\left\{\frac{P i}{1-P i}\right\}=\beta_{\mathrm{o}}+\beta_{1} X_{1}+\ldots \ldots \ldots+\beta_{\mathrm{k}} \mathrm{X}_{\mathrm{k}}+\mathrm{u}_{\mathrm{i}}
$$


The unknown parameters $\beta_{i}$ are usually estimated by maximum likelihood. Thus, model is explicitly express as:

$$
Z_{i}=\beta_{o}+\beta_{1} X_{1}+\beta_{2} X_{2}+\ldots \ldots \ldots+\beta_{8} X_{8}+u_{i}
$$

Where:

$Z_{i}=$ Standard logistic function of $P_{i}$

$\beta_{\mathrm{o}}=$ Constant term

$\beta_{\mathrm{i}(\mathrm{i}=1,2 \ldots .8)}$ parameters to be estimated

The independent variable $(x)$ would be:

$X_{1}=$ Sex: $(1$, if male and 0 if female)

$\mathrm{X}_{2}=$ Age (years)

$X_{3}=$ Marital status ( 1 , if married and 0 if single)

$\mathrm{X}_{4}=$ Household size (number of persons)

$\mathrm{X}_{5}=$ Level of education (years)

$\mathrm{X}_{6}=$ Farm size (hectares)

$\mathrm{X}_{7}=$ Farming experience (years)

$\mathrm{X}_{8}=$ Contact with extension agents (years)

$\mathrm{U}_{\mathrm{i}}=$ Independent distributed error term.

\section{Results and Discussion}

\section{Socioeconomic Characteristics of Rice Farmers}

Table 1 shows the percentage distribution of respondents according to their socioeconomic characteristics. The results showed that majority $(55.0 \%)$ of the respondents were males while $45.0 \%$ were females. This shows that rice farmers in the study area were dominated by men. This may be attributed to the fact that men as the head of households engage in farming activities to carter for the needs of the family. This finding however is in contrast with that of Asadu (2011) who reported that women were the majority among the farmers worldwide.

Most $(48.0 \%)$ of the respondents were within the age of 36-45 years $(48 \%)$ followed by those within the range of 46 years and above $(36.0 \%)$, those between 21 35 years were $13 \%$. The average age was 39 years indicating that they are still in their active years. This suggests that the likelihood of adopting innovations meant to improve rice production may be high as adoption of innovation is easier with venturesome people (Aphunu et al., 2008).

Table 1 also shows that many $(48.0 \%)$ of the respondents had rice farming experience of between 6-20 years. This implies that most of the respondents were well experienced in rice farming and are expected to have acquired relevant skills as well as willing to adopt innovations for effective farm operations. Educational status also reveal that many ( $49 \%$ ) of the respondents had tertiary education. This is advantageous because the people's assimilation rate will be enhanced by high educational status as education has positive relationship with quick understanding (Doss, 2003). However, the finding is in contrast with that of Asadu (2011) who reports that in Makelle, Ethiopia, rice farmers generally have low educational status. Majority $(63.0 \%)$ of the respondents operated between 1-3 hectares (1ha.) of farm land. This result indicates that farmers in the study area were within the small scale farming category. The implication of this on adoption is enormous as they believe 
that it is possible for them to manage the farms at a low technology level. The results in Table 1 further show that majority $(62.0 \%)$ of the respondents did not belong to any cooperative group. The low participation of the respondents in social groups poses a serious disadvantage to them because they would not enjoy any of the benefits of cooperative in information sharing and also that intervention agencies prefer to deal with farmers' groups. This is position is consistent with Agbamu (2006) that the greater the participation of a farmer in social organization, the more interaction with other farmers and hence the more innovative he becomes.

The level of extension contact of by farmers was also analyzed and the result in Table 1 show that majority (51\%) of the respondents had no extension contacts. The poor extension contact may be due to inadequate number of village extension agents within the state ADP. It is to be noted that this circumstance is not healthy for effective adoption of innovation since the innovation must be disseminated first. The findings agree with Chilot (1994) who found that extension contact had a significant effect on technology adoption. Table 1 further shows that majority $(66.0 \%)$ of the respondents had annual income of above N151, 000 per annum. The mean annual income of the respondents was N 120,000.This shows that rice farmers in the study area were small income earners. This low income status might reduce their ability to procure capital intensive technologies as income level has a positive relationship level of technology adoption (Chilot, 1994).

Table 1

Percentage Distribution of Respondents Based on Socio-Economic Characteristics $(n=100)$

\begin{tabular}{lrr}
\hline \multicolumn{1}{c}{ Socio-economic characteristics } & Frequency & Percentage \\
\hline Sex & 55 & 55 \\
Male & 45 & 45 \\
Female & $\mathbf{1 0 0}$ & $\mathbf{1 0 0}$ \\
Total & & \\
Age & 3 & 3.0 \\
$\leq 20$ & 13 & 13.0 \\
$21-35$ & 48 & 48.0 \\
$36-45$ & 36 & 36.0 \\
$\geq 46$ & $\mathbf{1 0 0}$ & $\mathbf{1 0 0}$ \\
Total & & \\
Marital status & 16 & 16.0 \\
Single & 84 & 84.0 \\
Married & $\mathbf{1 0 0}$ & $\mathbf{1 0 0 . 0}$ \\
Total & & \\
Farming experience & 42 & 42.0 \\
1-5years & 48 & 48.0 \\
6-20years & 10 & 10.0 \\
$>$ 20years & $\mathbf{1 0 0}$ & $\mathbf{1 0 0 . 0}$ \\
Total & & \\
Level of education & 2 & 2.0 \\
Non formal education & 5 & 5.0 \\
Primary education & 44 & 44.0 \\
Secondary education & 49 & 49.0 \\
Tertiary education & $\mathbf{1 0 0}$ & $\mathbf{1 0 0 . 0}$ \\
Total & & \\
& & \\
\hline
\end{tabular}


Table 1 cont'd $^{\prime}$

\begin{tabular}{|c|c|c|c|}
\hline \multicolumn{4}{|c|}{ Primary occupation } \\
\hline Farming & & 50 & 50 \\
\hline Teaching & & 39 & 39 \\
\hline Trading & & 9 & 9 \\
\hline Others & & 2 & 2 \\
\hline Total & & 100 & 100 \\
\hline \multicolumn{4}{|c|}{ Household size(numbers) } \\
\hline $1-5$ & & 54 & 54 \\
\hline $6-10$ & & 41 & 41 \\
\hline$\geq 11$ & & 5 & 5 \\
\hline Total & & 100 & 100 \\
\hline \multicolumn{4}{|l|}{ Farm size(ha) } \\
\hline $1-3$ & & 63 & 63 \\
\hline $4-6$ & & 23 & 23 \\
\hline$>6$ & & 14 & 14 \\
\hline Total & & 100 & 100 \\
\hline \multicolumn{4}{|l|}{ Annual income(naira) } \\
\hline$\leq 50,000$ & & 3 & 3 \\
\hline $51,000-100,000$ & & 4 & 4 \\
\hline $101,000-150,000$ & & 37 & 37 \\
\hline$\geq 151,000$ & & 56 & 56 \\
\hline Total & & 100 & 100 \\
\hline $\begin{array}{l}\text { Membership of } \\
\text { association }\end{array}$ & farmer & & \\
\hline Yes & & 38 & 38 \\
\hline No & & 62 & 62 \\
\hline Total & & 100 & 100 \\
\hline \multicolumn{4}{|l|}{ Extension contact } \\
\hline Yes & & 59 & 59 \\
\hline No & & 41 & 41 \\
\hline Total & & 100 & 100 \\
\hline \multicolumn{4}{|l|}{ How often if yes } \\
\hline 1-5times & & 49 & 49 \\
\hline $6-10$ & & 0 & 0 \\
\hline Not at all & & 51 & 51 \\
\hline Total & & 100 & 100 \\
\hline
\end{tabular}

\section{Sources of Agricultural information}

The results of the sources of information on rice production technologies are presented in Table 3. The entries show that majority $(85.6 \%)$ of the respondents have radio as their source of information on rice production technologies. This could be because of the presence of Joy radio that which has series of agricultural programmes. It is noteworthy that educational profile of the people in the study area could make them to develop interests in radio programmes especially the ones that 
serve their interests like agricultural programmes since the people are predominantly farmers. Although, Ramchandani (2004) pointed out in an earlier study that radio and television provides means for quick and wide dissemination of agricultural information and appealing messages, the recipient of such messages must be able to afford it in terms of cost and simplicity.

Table 2

Sources of Information on Rice Production Techniques to Respondents ( $n=100)$

\begin{tabular}{lcc}
\hline Sources & Frequency $^{*}$ & Percentage \\
\hline Radio & 113 & 94.2 \\
Television & 2 & 1.7 \\
Cooperatives & 1 & 0.8 \\
Internet & 1 & 0.8 \\
Fellow farmers & 55 & 45.8 \\
Print media & 1 & 0.8 \\
Community leaders & 3 & 2.5 \\
NGOs & 2 & 1.7 \\
Universities \& research institute & 1 & 0.8 \\
Extension Agents & 9 & 7.5 \\
Farmers Association or Group & 4 & 3.3 \\
friends and Neighbours & 2 & 1.7 \\
\hline
\end{tabular}

*Multiple responses recorded

Source: field survey 2017

\section{Rice Production Technologies Introduced to the Study Area}

Table 3 shows the distribution of rice production technologies introduced to farmers in the study area. The table reveals that majority of the respondents $(93 \%)$ agreed that improved seed varieties were the most predominant technologies introduced. This is where extension services are cardinal since the seeds have rates and other agronomic requirements for effective productivity. It is not enough to have the seeds available, affordability and usability should be factored into the adoption process for sustainability.

Table 3

Distribution of Respondents According to Rice Production Technologies ( $n=100)$

\begin{tabular}{lcccr}
\hline \multirow{2}{*}{\multicolumn{1}{c}{ Production technologies }} & \multicolumn{2}{c}{ Frequency } & \multicolumn{2}{c}{ Percentage } \\
\cline { 2 - 5 } & Yes & No & Yes & No \\
\hline Improved grain varieties & 93 & 7 & 93 & 7 \\
Land preparation size & 69 & 31 & 69 & 31 \\
Pesticide application & 90 & 10 & 90 & 10 \\
Fertilizer application & 78 & 22 & 78 & 22 \\
Manual weeding & 97 & 3 & 97 & 3 \\
Herbicide application & 75 & 15 & 75 & 15 \\
Disease and pest control & 89 & 11 & 89 & 11 \\
Appropriate spacing & 74 & 26 & 74 & 26 \\
Harvesting & 64 & 36 & 64 & 36 \\
Storage & 35 & 65 & 35 & 65 \\
\hline
\end{tabular}




\section{Effects of Socio-economic Characteristics of Respondents on their Level of Access to Agricultural information}

In order to determine the effects of social characteristics of respondents on rice technologies adoption decision, a logistic regression analysis carried out, and the result is presented in Table 5. The analysis show that level of education $(W=9.606)$, farm size (sig=0.022), have significant and positive effects on adoption decision at 1 $\%$ level of probability. This implies that respondent with higher level of education and larger farm size has greater probability of making quick adoption decision. This is because individuals with high level of education can access agricultural information from various sources, process those information at faster rate than someone who is less educated. It is also possible that, farmers who have large farm lands would require more technological intervention to facilitate their works and productivity.

The chi-square value of the logit regression model is 13.388 and is significant at $10 \%$ level of probability (sig. $=0.063$ ). This implies that the social characteristics of the respondents significantly affected their adoption decisions of rice technologies. The Nagelkerke $\mathrm{R}^{2}$ for the regression is 0.161 , indicating that the variables tested accounted for only $16.1 \%$ of the variations in the dependent variable, meaning that more social variables may account for farmers' adoption decisions. The null hypothesis which states that selected social characteristics of farmers have no significant effects on adoption decision was therefore rejected.

Table 4

Effect of the Socio-Economic Characteristics of Respondents on Their Adoption Decision

\begin{tabular}{|c|c|c|c|c|c|}
\hline $\begin{array}{l}\text { Socio-economic } \\
\text { Characteristics }\end{array}$ & Coefficient & $\begin{array}{c}\begin{array}{c}\text { Standard } \\
\text { error }\end{array} \\
\end{array}$ & Wald & Sig & $\operatorname{Exp}(B)$ \\
\hline Educational level & 1.606 & 0.518 & 9.606 & $.002^{*}$ & 4.983 \\
\hline Farming experience & 0.003 & 0.035 & 0.008 & .928 & 1.003 \\
\hline Marital status & 0.132 & 0.576 & 0.053 & .818 & 1.142 \\
\hline Household size & 0.012 & 0.051 & 0.054 & .816 & 1.012 \\
\hline Farm size & 0.020 & 0.089 & 2.051 & $.022^{*}$ & 1.020 \\
\hline Income & 0.000 & 0.000 & 0.154 & .695 & 1.000 \\
\hline Constant & 0.301 & 0.912 & 0.109 & .742 & 1.351 \\
\hline $\begin{array}{l}X^{2}=13.388 . \text { Sig. }=0.063 \\
\text { 2log likelihood } 115.924 \\
\text { Nagelkerke } R^{2}=0.161\end{array}$ & & & & & \\
\hline
\end{tabular}

\section{Conclusion and Recommendation}

Based on the findings of this study, it was concluded that the social profiles of the farmers were low and therefore responsible for the low adoption level since the chi square statistics show a clear relationship between social characteristics and adoption decisions. It can be further concluded that radio as the major source of information on agricultural development activities may not be sufficient for proper 
dissemination of agro allied information as studies have shown that mass media are not particularly effective tools for overt change in behavior.

\section{References}

Agbamu, J. U. (2006). Essentials of Agricultural Communication in Nigeria. MalthousePress Limited Lagos. P. 47 - 81.

Aphunu, A. (2011). Review of Technology adoption theories, measurement and analysis inagricultural extension p. 1 - 32.

Asadu A.N (2011). Adoption of gender-specific innovation by Women groups in Enugu-North Agriculture; Zone pre-Ph.d Research Seminar Pp 8-50.

Chilot Yirga, (1994). Factors Influencing Adoption of New Wheat Technologies in theWolmera and Addis Alem Areas of Ethiopia. An M.Sc. thesis presented to the Schoolof Graduate studies of Alemaya University of Agriculture, Ethiopia. 108p

Dontsop. N.P., Diagne, A, Okoruwa, V.O, and Ojehomom V (2011). Impact of improvedRice technology on income and poverty among Rice farming Household in Nigeria: AContributed Paper prepared for the 25th conference of the centre for the studies ofAfrican Economic (SAT) St. Catherine Collage, university of Oxford, UK 20-22March 2011.

Doss, C. R. and Morris, M. L. (2001). How does gender affect the adoption ofagricultural innovation? The case of improved maize technology in Ghana,Agricultural Economics pp 25, 27 - 39.

Ejembi, E. P., Omoregbee, F. E. and Ejembi, S. A. (2006). Farmers assessment of the training and visit extension system in central Nigeria: evidence from BarkinLadi, plateau state. J. Soc. Sci. 12(3):207-212.

F.A.O (2001). Farming systems and poverty: improving farmers' livelihoods in a changeworld. Rome: Food and agricultural organization

FAO (2014). http:/ / Faostat.fao.org.

Imolehin, E. D. and Wada, A. C. (2000). Meeting the Rice Production and Consumptiondemand of Nigeria with improved Technologies. National Cereal ResearchInstitute,Badeggi,PMB8,Niger State, Nigeria.pp1-11.

IRRI (1996) International Rice Research Institute Rice Genetics III. Proceedings of the ThirdInternational Rice Genetics Symposium. EDITED By G. S. KHUSH. Page 1.

Manyong, V. M. and Houndekon, V. A. (2000). Land Tenurial System and theDerived Savannas of West Africa. International food Policy Research Institute2033 K Street, N. W. Washington, D.C. 2006 U.S.A.

National Population Commission (NPC) (2006). Population figure. Federal Republicof Nigeria, Abuja. Retrieved from http://www.npc.gov.

Ramchandani, S (2004). Modern Methods and Techniques of Teaching.Dominant Public \& Distributors, New Delhi, India.

Saka, J. O. and Lawal, B. O. (2009). Determinants of adoption and productivity of improvedrice varieties in south western Nigeria. African Journal of Biotechnology. Vol. 8(19), pp. 4923 - 4932, 5th October 2009. 